\title{
Branding Analysis in Development Effort Kota Lama Semarang's Tourism Destinations
}

\author{
Gracia Angela Harianto ${ }^{1}$ Gregorius Genep Sukendro ${ }^{*}$

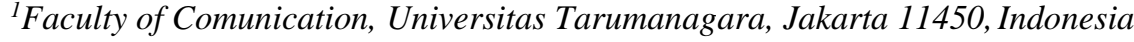 \\ *Corresponding author. Email: geneps@fikom.untar.ac.id
}

\begin{abstract}
Indonesia has many tourist areas and is very popular with tourists including foreign tourists. One of them is Semarang, which is one of the largest cities in Java Island. In this city there are four cultural sites of Semarang Lama, one of which is the Tourist Area of Kota Lama which is located in the middle of semarang city. Kota Lama is one of the icon cities of Semarang, as a tourism that contributes to the regional economy. Therefore, there needs to be a strategy to increase tourist attraction, one of the strategies for developing tourist destinations is by branding. Branding activities focus on building the image or image of the tourism and of course will involve stakeholders in this case, namely internal stakeholders and external stakeholders. The purpose of this research is to know the external perception of stakeholders on the quality and icon branding of Kota Lama Semarang, brand strategy carried out by internal stakeholders, as well as the development of tourist destinations in Kota Lama. While the theories and concepts used in this research are perception, brand strategy, city branding, tourism, and creative economy. This research uses qualitative approach with case study method. The data was obtained from interviews with two key informants and one supporting informant. The results showed that the branding quality of Kota Lama Semarang is much better than before.
\end{abstract}

Keywords: Branding, Perception, Tourism

\section{INTRODUCTION}

One of the largest sectors in the globalization era today is tourism. This is what makes tourism the main source in generating foreign exchange. In addition, tourism is also seen as an economic activity both for the community and for the State itself. Tourism also has a very big role in terms of national development. This is because in addition to being able to generate income or income, the tourism sector can also be used as a source of foreign exchange income [1].

In Law No. 10 of 2009, explained that tourism is an activity related to tourism, including the business of an object and also as an attraction for tourists and also all businesses related to the implementation of tourism activities. Therefore, it can also be interpreted that tourism activities are an activity that includes tourist travel, the business of an object and tourist attractions, and also the business of both services and facilities of a tourism [2].

Therefore, tourism must have its own attraction that aims to attract tourists in order to visit the tourist site. One of the activities in the effort to develop a tourism is by branding. According to Kotler, each location can be branded by creating and communicating a separate identity of the destination or place to a wide audience. The term branding according to Landa develops from the limited brand or name of a product, service or company that has a connection with the physical things of a brand such as name, logo, or other visible physical characteristics into a credibility, character, perception, impression, image and also opinions of the audience [3]. Brand as an identity of course has an advantage and can create a positive perception in the eyes of the audience because of the power of branding owned and viewed so that it can influence the increase in sales and build brand awareness in the eyes of the audience [4].

In addition, Kotler and Keller described that branding is an effort or an activity that includes a product or service with the power of a brand [5]. According to him, a brand is a perceptual entity that has roots in an existing reality, but reflects a perception even the thoughts and feelings of consumers.

In the sight of marketing glasses, branding activities in a place or destination has the aim to find and even attract investors, businesses, and tourists. Branding activities can help the success of a brand in communicating and attracting audiences. In addition, it can also help increase a product value and also brand value becomes stronger so that it affects audience decision making [6]. Branding activities are one of the inseparable strategies in the world of marketing, namely an effort to market brands into a market [7].

Indonesia as one of the countries that has a lot of areas that are rich in tourist attractions and very popular with 
tourists including by foreign tourists to travel and visit tourist attractions in Indonesia. One of them is Semarang, which is one of the largest cities in Java Island. In this city there are many historical relics, both from the HinduBuddhist era and colonial or colonial times. Some of the remaining historical relics, one of which is the Tourist Area of Kota Lama which is located in the middle of semarang city. Kota Lama Semarang's tourism is a tourist destination that has unique characteristics, in addition to the Old City is one of the four cultural sites in the city of Semarang, namely Kampung Melayu-Arab, China townChina, Kauman-India, Kota Lama-Indis (Indonesia, West, China). Old buildings with Dutch architecture in Kota Lama are still standing tall and maintained their authenticity until now.

With This Old Town as one of the tourist attractions, in the profit-based industry sector is in desperate need of branding in attracting several stakeholders, Kotler also explained that a brand not only reaches its customers, but also reaches its stakeholders. Therefore, every tourist destination must have their own brand image. The reason is because tourism is one of the imaging-based industry sectors. So the role of image or image is an important element for tourist destinations. Therefore, efforts are needed in marketing destination of Kota Lama Semarang through branding strategy. With this, it can be concluded several problem formulations, namely How is the brand strategy and development efforts carried out by internal stakeholders towards the tourist destinations of Kota Lama Semarang? What is the external perception of stakeholders (tourists) on the quality and icon branding of Kota Lama Semarang's tourist destinations? This research is to find out the perception from stakeholders about the quality and icon of Kota Lama Semarang's destinations and also its development efforts.

\subsection{Related Work}

\subsubsection{City Branding Analysis in Destination Development Jayapura Regency Tourism}

This journal was written by Ari Bawandi from AMPTA Yogyakarta Tourism College in 2016. The contents of this journal are tourism market players stating that the image or image for Jayapura Regency as a comfortable and interesting city. The secretary of Jayapura Regency is one of them is caused by the existence of Lake Sentani which is widespread in Jayapura Regency. The diversity of natural tourism and culture of the community is unique. The uniqueness of Jayapura Regency is what distinguishes Jayapura Regency from its main competition, namely Jayapura City and Sarmi Regency. There is no difference in perception between tourists who have just visited for the first time (first time visitor) and tourists who have visited repeatedly (repeator visitor), which makes the District interesting because of its diverse natural tourism and cultural community that has its own uniqueness. In addition, the elements of brand formation that are suitable for arranging city branding Jayapura Regency is unique, comfortable, safe Lake Sentani, Lake Love, Nature Tourism, Community Culture are elements of brand formation that can be used to compile city branding Jayapura Regency. While that can be used as a symbol or icon of Jayapura Regency is Lake Sentani.

\subsubsection{Indonesian Tourism Branding Strategy for Foreign Marketing}

This journal was written by Ghifari Yuristiadhi and Shintya Dewi Lupita Sari from The Vocational School of Gajah Mada University. The results showed that branding used since 2015 to date is Wonderful Indonesia for foreign markets and Pesona Indonesia for domestic market. Previously, since 2008-2015 the Government of the Republic of Indonesia used Visit Indonesia. Ministry of Tourism uses four media used as a means of publication and promotion, namely online media, electronic media, print media, and space media. Wonderful Indonesia branding is significant enough to attract Chinese tourists who jumped to $42.22 \%$ in 2017 , but have not been successful enough in other countries. Through branding, the Ministry of Tourism has not succeeded in realizing 15 million foreign tourist visits by the end of 2017

\subsubsection{Branding done by Public Relations at Private Universities}

This journal was written by Yugih Setyanto, Paula T. Anggarina, and Anny Valentina in 2017. The result of this research is Branding conducted by Public Relations at the University of THasil writing shows that Branding at private universities needs to be done in order to strengthen reputation. Reputation must be shaped through good performance. Public Relations plays a role in branding efforts. Branding is not only done in the realm of marketing as it has been understood. Of course, the part that public relation does in branding is to build communication about the brand of private universities.

\section{BACKGROUND}

\subsection{Perception}

Perception is the brain's ability to translate the stimulus that enters the human senses. Perception is a process of organizing, interpreting the stimulus received by groups or individuals so that it becomes something meaningful and is an integrated activity in the individual.

Everyone has a tendency to see objects in different ways. These differences can be influenced by several factors, including knowledge, experience and point of view information obtained through the human sensory system. There are three aspects in perception that are relevant to human cognition, namely senses, pattern recognition. It can be analogized that the perception is like a file that has 
been neatly stored in the pician consciousness. Perception can also be defined by the brain's work in assessing or understanding what is happening around it perception is a process of interpreting and attention. Meanwhile, according to Jalaludin Rakhmat in stated that perception is observation of objects, tourism or relationships obtained by concluding information and interpreting messages [8].

\subsection{City Branding}

City Branding according to Kavaratzis in generally focuses on image management, more precisely what and how the image of the destination is formed [9]. The concept of city branding is basically the same as the concept of branding and has six components to provide value for stakeholders, including: percentce (presence), potential (potential), place (place), people (people), pulse (spirit), prerequisite (prerequisite). City branding is the image management of a destination through strategic innovation as well as economic, commercial, social, cultural and government regulation coordination.

The concept of city branding that starts from place marketing is the development of economic potential in urban locations City branding is a strategic process to communicate the image of a city or region to all interested parties, including city residents, tourists, investors and so on. Meanwhile according to Anholt, city branding is the management of the city's image through strategic innovation as well as economic, social, commercial, cultural and government regulation coordination [10].

\subsection{Brand Strategy}

Brand strategy is a part of the concept of brand management, as to realize the development of products, where marketing management consists of planning, analysis, strategy, development and brand audit. Brand strategy becomes a marketing strategy option to build an identity or character to be able to look superior and different from other tourism. Brand Strategy is the management of a brand where there are activities that regulate all elements with the aim of forming a strong brand [11].

\subsection{Creative Economy}

The Ministry of Trade of the Republic of Indonesia (2008) formulated the creative economy as an effort to develop a sustainable economy through creativity with a competitive economic climate and having renewable resource reserves. A clearer definition was conveyed by UNDP (2008) which formulated that the creative economy is an integrative part of innovative knowledge, creative use of technology, and culture. Indonesia is a country with many tribes and cultures, so every region that has a culture can present its culture in unique ways [12].

\section{METHODS}

In this research, the approach used is qualitative approach. Researchers chose this approach because it is in accordance with the title of the research, namely branding efforts in the development of tourist destinations in Semarang Old Town.

According to Moleong, the definition of qualitative research is research that has the intention to understand a phenomenon of what is experienced by research subjects such as behavior, perception, motivation, action, and others holistically and through the way of description in the form of words and language in a special context that is natural by utilizing various scientific methods. In order to understand the problems in this study, the researchers interviewed key informants as well as informants by asking several questions related to the theme of the study. Furthermore, the information obtained in the form of word and text data is collected and then analyzed. The data collection method that researchers use is using three methods, among others; in-depth interviews, observations, and documentation.

a. Indepth interview. Primary data is sourced from indepth interviews. Informants are selected based on how much information can be obtained for the purposes of this research. In this case, researchers interviewed two key informants namely Transiska Luis Marina, ST., MM. as the head of control section of Semarang Spatial Office and also Jessica Melinda as a tourist of Kota Lama. As well as an additional informant, Rikha Anastasia as the old city tourist guard.

b. Observation. Observations in the field are very necessary to help in adjusting the data with the facts of existing reality. In addition, with the observation, it can strengthen the data and deepen the information that has been submitted by the informant. In the context of this research, researchers conducted direct observation activities in the location of Kota Lama's area of Semarang in order to obtain the reality facts of Kota Lama.

c. Documentation. Search for additional data in the form of information from various sources such as print, visual and sound. This is in order to obtain information to support the results of data analysis and interpretation. In the context of this research, researchers searched for documentation data in the form of books, online journals, websites to obtain additional information related to research.

\section{FINDINGS AND DISCUSSIONS}

\subsection{Efforts to develop tourist destinations of Kota Lama Semarang conducted by internal stakeholders}

Related to branding in the old city development efforts, based on the results of an interview with Mrs. Transiska Luis Marina, ST., MM. y suggested that branding is an 
activity to re- squeeze an object or product in order to create a new impression in the eyes of consumers. In the context of the old city of Semarang, branding efforts are carried out by structuring the area / revitalization which means it is a process and an act to revive something that was previously neglected in the form of buildings around the Old City area of Semarang into a useful and managed building. In other words, overall from the side of the building is still the same physical branding that is done in the form of reorganization of the area and makeover of buildings, streets, and facilities of the Old City to look more neat and clean and able to compete with competitors or in this context is another tourist attraction. The purpose of branding for the Old City tourism area is because Semarang Old Town is one of the Old Semarang sites that received the title as one of the National Heritage areas. Therefore, branding activities are believed to help Kota Lama as one of the cultural heritages in maintaining its sustainability and utilization. The relationship of theory with the results of the interview is that along with the development of global capitalism, there is a slight shift that was originally from marketing to branding. In this context, the shift in question is from place branding to place branding. The purpose of branding activities in tourist destinations is to improve relationships or a business investment relationship and promote economic and social development to the audience. In addition, to improve the competitive position of tourism. In the context of tourism, branding activities can strengthen a destination in order to be able to compete and be different from its competitors. This can be seen from the branding activities carried out in the Old City area, namely by revitalizing or reorganization of the area in order to be able to compete with its competitors.

\subsection{External perception of stakeholders (tourists) on the quality and icon branding of Semarang Old City tourist destinations}

The external perception of stakeholders on the quality of branding and icon of Kota Lama destinations is the quality of the Old City area of Semarang today after the enactment of revitalization, much more attractive and increasingly crowded with visitors / tourists. In addition, according to tourists, the quality of facilities, facilities and infrastructure of Semarang Old Town is now much better than at the time before the revitalization. This is because currently, Kota Lama Semarang has more complete facilities, facilities and infrastructure to meet the needs of the visitors of Semarang Old Town. As for the quality of safety and comfort of Semarang Old City tourism, these tourists feel better comfort and security than before. This is because the revitalization of totality provided by the government for kota Lama so that it can provide services and quality that is very attractive to its visitors. And also for access to tourist attractions Kota Lama Semarang is very easy to find and reach the tourists. This is because the strategic location of Semarang Old Town is in the center of Semarang city and is familiar to the people especially the people of Semarang City. So that it can make it easier for tourists to visit the tourist location of Semarang Old Town.

According to Jessica Melinda as a tourist, the icon of Semarang Old Town tourist destination is Blenduk Church. This is because the location of Blenduk Church is quite strategic, namely in the heart of the Old City tourist area and it is certain that the tourists must pass through the Blenduk Church. In addition to its location, the Dutch architectural building in Blenduk Church is still very thickly visible, thus giving its own characteristic that is very unique for the church building.

The relation of the theory with the results of the interview is the perception of tourists is a process of interpreting the information obtained through the human health system that is in the form of interpretation of information obtained through the branding quality of Semarang Old Town received by tourists. In theory there are three specs in perceptions relevant to human cognition, namely senses, pattern recognition and attention. In the context of tourists' perception of the branding quality of Kota Lama, relevant to the cognition of tourists, namely the senses that are able to see and feel the condition and quality of the Old City branding icon until a response is formed that occurs in the tourists so that they are aware of everything around it through its sensory tools.

\subsection{External perception of stakeholders (tourists) on the quality and icon branding of semarang old city tourist destinations}

Brand strategy in the development of Kota Lama includes three components, namely:

\subsubsection{Brand Identity}

In this case the identity of the Kota Lama's area itself is along the road Letdjen Suprapto. Because it is clear that the center of the crowd itself is along the street. The street is the heart of Kota Lama's area because along the street there are many familiar buildings such as Blenduk Church, Srigunting Park, Oudetrap Building, Javara Building, MSME Gallery and others.

\subsubsection{Brand Personality}

Brand personality owned by the Kota Lama Semarang is not only an area with tourist or entertainment purposes, but this kawasasan also has educational and cultural value. So that the tourists who visit the Kota Lama's area of Semarang is not only limited to obtaining entertainment, but also gaining a knowledge and of course about the existing culture.

\subsubsection{Brand Positioning}

Kota Lama Semarang's tourism area as one of the National Cultural Heritage areas, one of which is able to 
maintain the physical buildings of the dutch colonial period that still stand firmly even though it has been hundreds of years old. In addition, although the building is an old building or kono, but the buildings along the area are still maintained and able to create a unique impression that attracts tourists to visit the area to travel and take pictures and enjoy other entertainment available in the area. In the Kota Lama's area, rarely found buildings that mangkrak or not functionalized. The majority of buildings are old and dull, but the city spatial office continues to strive to maximize each existing building to be functionalized into a building that is beneficial for tourists.

\section{CONCLUSIONS}

Researchers concluded some conclusions that are the result of the author's research is the perception of external stakeholders (tourists) to the branding of tourist destinations Kota Lama Semarang is the quality of facilities, facilities and infrastructure of Semarang Old City tourism according to tourists is much better than before. While the quality of safety and comfort is also better than before it is even more comfortable because there are currently more complete facilities. For accessibility is very easy to be reached by tourists who want to attend the tourist area of Kota Lama Semarang. And also for the destination icon in the Old City area is Blenduk Church. While the Brand Strategy carried out by internal stakeholders towards The Old City Tourism Destination of Semarang is by determining the brand positioning of Semarang Old City tourism, determining the brand personality of Semarang Old Town tourism, determining the brand identity of Semarang Old City tourism. In addition, the development of semarang old city tourist destinations carried out by Internal Stakeholders is by paying attention to revitalization for the old city of Semarang tourism, namely by making over in other words dressing up unkempt buildings to be more attractive so that it can be utilized as it should be, the management of unused buildings / magkrak so that it can be functionalized into a tourist attraction, as a National Cultural Heritage area, The Old City which was originally only limited to art deco nuances, is currently an area that not only presents entertainment / tourism but as an area that provides cultural and educational value. Meanwhile, in order to strengthen the reputation, branding activities in tourist destinations are very necessary. A reputation must be built through a good performance. In this context, Public Relations plays a role in branding efforts. Branding is not solely done only in the field of marketing / marketing. However, in the context of branding this tourist destination, Public Relations has a duty and role to build communication about a brand of tourist destinations to a wide audience.

\section{ACKNOWLEDGMENT}

Researchers give praise and gratitude to God almighty for His Blessings and Mercy, so that researchers can complete this research in time. This research would not have materialized without the help of various parties. Therefore, the researchers thanks the thesis supervisor, Mr. Gregorius Genep Sukendro, S.Sos., M.Si who always provide guidance, input, motivation in the work of this research. And also for the speakers who have been willing to spend their time are Transiska's mother, Jessica, and Rikha. In addition, researchers would also like to thank the family and friends who have supported and encouraged the researchers.

\section{REFERENCES}

[1] Kristiutami, Y. P. (2014). Kawasan Produksi Seni Pahat Batu Sebagai Daerah Tujuan Wisata Di Kabupaten Magelang. Pariwisata, I (2), 64-71.

[2] Widiastuti, N. K. (2013). Pengaruh Sektor Pariwisata Terhadap Kinerja Keuangan Daerah Dan Kesejahteraan Masyarakat Kabupaten/Kota Di Provinsi Bali. E- Jurnal Ekonomi Dan Bisnis Universitas Udayana, 2(5), 292 311

[3] Landa, Robin. (2006). Designing Brand Experiences. Thomson Delmar Learning

[4] Wasil, M. (2018). Pengaruh Brand Awareness, Brand Association, dan Percieved Quality. Forum Ekonomi.19(2).137.

[5] Kotler, Philip, and Keller, K. L. (2009). Manajemen Pemasaran Jilid I: Jakarta: Erlangga.

[6] Setiawan, M. F. (2013). Analisa Pengaruh Food Quality dan Brand Image terhadap Keputusan Pembelian Roti Kecik Toko Roti Ganep's di Kota Solo. Jurnal Strategi Pemasaran.1(1).1-6

[7] Sukendro, G., \& Setyanto, R. L. Y. (2012). Stealth marketing sebagai strategi e- branding? (Analisis Diskursus Inkognito pada Grup Band Hijau Daun dalam Youtube). Jurnal Komunikasi. 1-20.

[8] Noorhafizh Firdaus, L., Setiawati, T., \& Nurhayati, A. (2018). Persepsi Santri Tentang Penyelenggaraan Makan di Pondok Pesantren Husnul Khotimah Kabupaten Kuningan. Jurnal Media Pendidikan, Gizi, dan Kuliner .7(2).44-50. 
[9] Widodo, B. (2016). Strategi Pencitraan Kota (City Branding) Berbasis Kearifan Lokal (Studi Kasus Di Kota Solo, Jawa Tengah Dan Kabupaten Badung, Bali) Bambang Widodo Dan Mite Setiansah (Dosen Jurusan Ilmu Komunikasi Fisip Unsoed Purwokerto). Jurnal Komunikasi.7(2)

[10] Kavaratzis, Michalis. (2004). From City Marketing to City Branding: Towards A Theoretical Framework for Developing City Brands, Place Branding Vol.1 (1), pp.58-73.

[11] Kusno, F., Radityani, A., \& Kristanti, M. (2007). Analisa Hubungan Brand Strategy Yang Dilakukan Goota Japanese Charcoal Grill And Cafe Dan Brand Equity Yang Sudah Diterima Konsumen. Jurnal Manajemen Perhotelan Vol.3 (1), pp.43-56.

[12] Ananda, A. D. (2018). Pengembangan Usaha Mikro Kecil Dan Menengah (Umkm) Berbasis Ekonomi Kreatif Di Kota Malang. Jurnal Ilmu Ekonomi.10(10).120-142.

[13] Sugiyono. (2008). Metode Penulisan Kuantitatif Kualitatif dan R\&D. Bandung: Alfabeta. 